\title{
PRE-SERVICE EFL TEACHERS' PERCEPTIONS AND ACTUAL PRACTICES OF GIVING ORAL FEEDBACK IN APPRENTICESHIP PROGRAM: EXPLORATORY STUDY
}

\author{
Atikah Wati ${ }^{* 1}$, Indra Yoga Prawiro ${ }^{* 2}$ \\ atikah wati@ unwir.ac.id $^{* 1}$, yogaprawiro@gmail.com ${ }^{* 2}$ \\ Faculty of Teachers Training and Education Science - English Education Department \\ University of Wiralodra
}

\begin{abstract}
The purposes of this study were to knowthe pre-service EFL teachers' perceptions of their own oral feedback in apprenticeship program and to investigate the types of oral feedback that pre-service EFL teachers use in apprenticeship. It is supported by some problems found in the previous year apprenticeship program, pre-service teachers were seldom to give feedback to their students' work or performance during the teaching and learning process, those pre-service teachers seem to be afraid to give more information or explanation about students' work, tell the students' incorrect work and give the students the correct answer explicitly, correct the students pronunciation, restate the correct form of students' utterances, etc. To achieve the purpose of study, the writer used qualitative research method. The research participants were be taken from English Department students of Wiralodra University Indramayu that applied for apprenticeship program, there were 20 students that experienced their apprentceship program inseveral schools in Indramayu.The instrument of the research were observation and questionnaire modified from Sultana (2015). The finding showed that pre-service teachers' were aware by the important of oral feedback to correct students' mistakes, clarify the incorrect information, correct the students' pronunciation, and restate the correct form of students' utterances. Unfortunately in the teaching and learning process many of pre-service teachers did not execute oral feedback when they have to. Most of the oral feedback given to the students were focused on mispronunciation, grammar and vocabulary. Preservice teachers seems did not notice misinformation mistakes and did not really aware of giving advice on students' performance as the improvement strategy
\end{abstract}

Keywords: Exploratory Study, Oral Feedback, Pre-service teachers' perception.

\section{INTRODUCTION}

Teaching practice plays important role to produce students of educational faculty into the candidates of professional teachers. There are many lesson programs that prepare these students meet the real duties of professional teacher, one of them is Apprenticeship Program. This program is to prepare and give experiences of being real teacher in the real school phenomenon. The students do not only learn how to teach but also learn how arrange lesson plan and other educational task 
such as participating in school activities, extracurricular, helping the officer duty and librarian, etc. As Richard (2010) pointed out the considerable need for qualified English language teachers across the globe and for more effective approaches to their preparation and professional development.

Many problems had been found during teaching practice conducted by preservice teachers, asin Dwiniasih (2007) explored pre-service teachers problem during teaching practice showed two main problems faced by pre-service teachers, problem on managing the class while handling the material and problem on handling the students when pre-service teachers tried to use new strategy as well as corrected the students errors during the teaching and learning process or problem in giving feedback.

Feedback has considerably been acknowledged as a significant component of language teaching. The way how pre-service teachers carry out and giving feedback in teaching practice are really important to support professional development of pre-service teachers to meet the learning objectives. As in Koc and Ilya (2016), they investigated the prospective teachers' perceptions of giving feedback in micro teaching implementation in Turkish. Feedback is one of the most powerful influences on learning and achievement in the teaching and learning process it provide information to both teacher and students on students' progress in acknowledging learning objectives. Furthermore, Pre-service teachers' choice of feedback is one of the important components during apprenticeship program to measure pre-service professional development. As Sadler (1989) stated that feedback is the key component of information that is given or is being given on how an action is being developed in term of its quality for success because one of the feedback characteristics is the usage of this information to improve the students' performance. Therefore, feedback that used by pre-service teachers need to be analyzed. It is supported by some problems found in the previous year apprenticeship program, pre-service teachers were seldom to give feedback to their students' work or performance during the teaching and learning process, those pre-service teachers seem to be afraid to give more information or explanation about students' work, tell the students' incorrect work and give the students the correct answer explicitly, correct the students pronunciation, restate the correct form of students' utterances, etc.

Based on the problems above, the topic about pre-service teachers can be set into larger area of researches to be investigated. What happen to pre-service teachers' actual practice in giving oral feedback during the teaching and learning process in schools?. So, the current study focused on exploring pre-service teachers' perception and the way how pre-service teachers giving oral feedback in apprenticeship program 


\section{LITERATURE REVIEW}

\section{The Role of Pre-service Teachers in Apprenticeship Program}

As a method to improve the quality of teacher education, apprenticeship program provide pre-service teachers with the teaching practice. It is has been regarded as an effective method offering the opportunity of planning and implementing new teaching strategies to pre-service teachers who can make the connection between the theory and practice. In this case, pre-service teachers also need to evaluate students' development and achievement to gain learning objectives. Pre-service teachers should ensure self-evaluation and peer to peer evaluation students. Pre-service teachers need to evaluate the students to improve their teaching process. One of the teaching process that expected be conducted by pre-service teachers is giving feedback whether it is constructive or explanatory feedback.

\section{Feedback}

Feedback is corrections and advises in detail and specific explanation to improve students' skills to meet the learning objectives. Kluger and Denisi (2017) stated that feedback is information provided to someone referring to his or her performance, while Hattie and Timperley (2007) mentioned feedback as information regarding aspects of students' performance and understanding, and recommendations to help learners become aware of any discrepancies between what they know and what they want to achieve. In this case, feedback is intended to help students correct or improve themselves.

Moreover, Hattie and Timperley (2007) explained that there are four major levels of feedback that directed influences students' skills. First, feedback can be about a task or product, such as the students' work is correct or incorrect. This level of feedback may include directions to acquire more, different, or correct information. Second, feedback can be aimed at the process used to create product or complete a task. This kind of feedback is more directed in processing information, or learning processes requiring understanding or completing the task. Third, feedback to students can be focused at the self-regulation level, including greater skill in self-evaluating or confidence to engage further on task. Fourth, feedback can be personal in the sense that it is directed to the self.

\section{Types of feedback and its function}

Evaluative, corrective and descriptive feedbacks are types of feedback found in Melati (2014), the following are its explanation:

1) Evaluative Feedback

Askew (2000) explained that it consist of approval (raise) and disapproval, confirmation, and encouragement.

a. Approval is a feedback that contains teacher's positive expression toward students' work. For example, the teacher can say 'you have done well' when students fulfill teacher expectation. In the other hand, disapproval contains negative expression toward students' work.

b. Confirmation tells whether students' statement is true or not. Mentioned confirming students' statements make them understand that they perform 
correct or incorrect performance. For example, teacher might say 'I agree with that!', or 'yes!'.

c. Encouragement is a moral support for students. It can be also teacher believe about students' ability. For example, teacher can say 'I'm sure you can do that', 'you can perform better' and 'you have to try harder'.

2) Corrective Feedback

Ellis (2006) defined corrective feedback is a response to a student's error. It is divided into six types, explicit, recast, clarification, request, metalinguistic, elicitation and repetition.

a. Explicit feedback tells students' incorrect utterance and gives the correct answer explicitly. For example, 'we don't pronounce ..., we pronounce ...', 'say..., not ...'

b. Recast means teacher correct students' utterance by restates the correct form of students' previous utterance which is incorrect. For example, students said 'where he go?' and teacher gives feedback 'where does he go?'

c. Clarification is used to clarify three possibilities. First, teacher misunderstands. Second, teacher does not hear clearly what students said. Third, students really make a mistake. Teacher usually repeats incorrect part of use interrogative sentence. For example, student said, 'it is new policy'. Teacher did not listen clearly the word 'policy' so the teacher gives feedback 'pardon me?' or 'policy?'.

d. Metalinguistic feedback is kind of feedback that requires students analyze their error and give explanation about the correct form of the answer. For example, the students said 'where he is study?' and teacher's feedback, 'um, can you think about your grammar? You need to use -ing form after auxiliary verbs such as am, is, are to indicate present continuous.

e. In elicitation feedback, teacher uses pausing strategy to let students 'fill in the blank' with the correct answer during pausing break. Students are expected to correct themselves while feedback process is happening. For example, student said 'she is run to her mother', and then teacher's feedback is 'she is...' or 'she is run...'. The expected answer is student would say 'running',

f. Repetition, teacher repeats the error word or sentence in students' utterance. Teachers adjust his intonation with aims students will notice their mistake and have initiative to correct it. For example, student said 'the air is so fresh'. In this case student pronounces 'air' incorrectly and teacher noticed it. Teacher would say 'Air?' adjusting their intonation to make student notice his mistake. The difference between repetition and clarification is, in repetition, teachers sure that students notice they make mistake but in clarification, teachers are not sure.

3) Descriptive feedback

Askew (2000) stated that descriptive feedback is specific information about what students do well, what they need to improve, and how they can improve. Descriptive feedback could be classified in three types, strength and weakness area to improve and improvement strategies. 
First, in strength and weakness feedback, teachers tell students' strength and weakness. Brown (2003) stated that skillful teachers need to be able to identify both the strength and weakness of their students and provide the students with constructive feedback on both side. Second, in giving feedback in the area to improve, teacher gives suggestions to improve, add or reduce specific things that students already had in their work or performance. And the last, Askew (2000) stated that in improvement strategy, teacher gives suggestion about other possible strategies which has not existed in the performance that students can do.

\section{RESEARCH METHODOLOGY}

\section{Research Method}

This research uses qualitative approach with case study design.Geertz cited in Cohen (2007) explained that case studies strive portray 'what it is like' to be in a particular situation, to catch the close up reality and thick description. According to Merriam cited in Dornyei (2007), qualitative case study as an intensive, holistic description and analysis of a single entity, phenomenon, or social unit. Case studies are particularistic, descriptive, and heuristic and rely heavily on inductive reasoning in handling multiple data sources.

This research used an exploratory nature which Eisenhardt cited in Dornyei (2007) defined it as effective way of exploring new, uncharted areas. If very little is known about a phenomenon, the detailed study of a few cases is particularly appropriate because it does not rely on previous literature or prior empirical finding. In this case,Pre-service teachers' perception and actual practice of giving oral feedback in apprenticeship program were explored and analyzed.

\section{Research Participant}

The participants of this research taken from the English Education Department students who take the apprenticeship program. According to the data of FKIP in 2018, there were approximately 40 students who joined the apprenticeship program next semester in at least 10 states or private senior high schools around Indramayu. Unfortunately, only half of it were able to be explored and analyzed.

\section{Data Collection}

Dornyei (2007) stated that qualitative research works with a wide range of data including recorded interviews, various types of texts and images (photo or video). While according to Yin (2008), the data collection of case study can be in various source. The data collection in this research used:

1. Observation: it is a research process that offers investigator the opportunity to gather 'live data' from naturally occurring classroom situation. Non participant observation was used in this research, because the role of researcher is usually not or only minimally involved in the setting (Cohen:2007). In this case, the role of researcher is as complete observer which typified in the one way mirror, the video, the audio and the observation 
checklist uses to capture the oral feedback part that executed by pre-service teachers. So, there were no intervention and manipulate the situation or subjects nor do or create provocations.

2. Questionnaire: The function of the questionnaire is to get the information related to the perception and actual practice in giving oral feedback from the participant. In this research, the questionnaire of pre-service teachers' perception and oral feedback were delivered to find out how pre-service teachers give oral feedback to their students in apprenticeship program. Close and open ended questionnaire were given to pre-service teachers.

\section{FINDING AND DISCUSSION}

\section{Pre-service Teacher's Perception}

This part of the finding deals with the pre-service teachers' perception of their own oral feedback in apprenticeship program. Based on the finding, $100 \%$ pre-service teachers' agree that oral feedback is really important in teaching and learning process. Their understanding related to the important of oral feedback can be summarizes as follow:

a. Through oral feedback, we directly interact to the students and if the students still confuse or have something to ask, they can directly say that to the teacher and teacher can give feedback about students' performance directly.

b. Oral feedback directly given to the students at the time. So, the students can understood it. The oral feedback make them comfortable

c. By oral feedback we know the reaction of students.

d. Students more understand clearly and easily know their mistakes from the feedback.

e. By oral feedback the students can ask clarification from the teacher.

From the above summary, it can be concluded that pre-service teachers' were aware by the important of oral feedback to correct students' mistakes, clarify the incorrect information, correct the students' pronunciation, and restate the correct form of students' utterances. Unfortunately in the teaching and learning process that can be seen from the observation not many of preservice teachers execute oral feedback when they have to. Related to the important of oral feedback, table 1 summarizes pre-service teachers' opinions regarding the meaning of oral feedback in their teaching in apprenticeship program as concluded from questionnaire. 
Table 1. Pre-service teachers' opinions of oral feedback

\begin{tabular}{|l|l|}
\hline \multicolumn{1}{|c|}{ The meaning of feedback } & \multicolumn{1}{c|}{ Pre-service teachers' opinions } \\
\hline Correcting mistakes & $\begin{array}{l}\text { a. I'll correct it directly if there are mistakes } \\
\text { b. To give clarification on what the correct } \\
\text { one. } \\
\text { c. Directly give the right pronunciation and } \\
\text { give the right example of the right } \\
\text { pronunciation }\end{array}$ \\
\hline $\begin{array}{l}\text { Constructive criticism and } \\
\text { advice/tips }\end{array}$ & $\begin{array}{l}\text { To give some additional information and } \\
\text { suggestion in order to make them improve }\end{array}$ \\
\hline Acceptability of the answer & $\begin{array}{l}\text { We can see the students' abilities in the } \\
\text { material that we convey }\end{array}$ \\
\hline $\begin{array}{l}\text { Positive and negative side } \\
\text { of the performance }\end{array}$ & $\begin{array}{l}\text { For negative side of the performance should } \\
\text { be done outside of the class in order to avoid } \\
\text { social humiliation }\end{array}$ \\
\hline Motivating the students & $\begin{array}{l}\text { a. The oral feedback make them comfortable } \\
\text { b. Can give motivation to the students } \\
\text { c. It can motivate the students }\end{array}$ \\
\hline
\end{tabular}

As can be seen from table 1, correcting the students mistakes was one of the reason of pre-service teachers' gave oral feedback so that the students directly realized their mistakes and understood how to correct it. The second reason was give advice or tips to students on how to improve their performance. Acceptability of the answer was third reason, pre-service teachers' keep saying "Good Job, Good" to indicate that they accept the students answer. The next one is positive and negative side of the performance. KOc \& Ilya (2016) stated that both negative and positive aspect should be paid attention. Pre-service teachers should give oral feedback on the positive and negative aspects of students' performance yet one of pre-service teacher suggested that for negative side of the performance should be done outside of the class in order to avoid social humiliation. Somehow, to improve students' performances, positive and negative feedback should be given clearly in order to minimize the mistakes that execute by the students. The last reason was pre-service teachers believes that giving oral feedback could motivate the students because pre-service teachers think it can make the students feel comfortable by knowing what they have to do to make it better the moment they perform.

In table 2, the responses of pre-service teachers to the question regarding the role of oral feedback they provided in apprenticeship program.

Table 2 the role of oral feedback by pre-service teachers

\begin{tabular}{|l|c|c|}
\hline \multicolumn{1}{|c|}{ The role of feedback } & Number & Percentage \\
\hline Encourage students & 4 & 20 \\
\hline Improve learning & 15 & 75 \\
\hline To guide the students & 1 & 5 \\
\hline
\end{tabular}


Overall, as the percentages presented in table 2 indicate the majority of pre-service teachers think that they employ oral feedback so as to improve students' learning $75 \%$. A few pre-service teachers think that oral feedback also to encourage the students which indicated by $20 \%$. And one pre-service teacher mentioned to guide the students $5 \%$ as one of the role of oral feedback too.

\section{The types of feedback}

This part deals with the types of feedback that executed by pre-service teachers in apprenticeship program. Evaluative, corrective and descriptive feedbacks are types of feedback based on Melati (2014) that will be analyze and describe in this part.

\section{a. Corrective Feedback}

Ellis (2006) defined corrective feedback is a response to a student's error. It is divided into six types, explicit, recast, clarification, request, metalinguistic, elicitation and repetition.One of pre-service teacher used recast in his feedback by trying to restating the correct form of students' previous utterance which is incorrect but didn't notice the grammar mistakes.

(1) S: "How's the sun can be life in the sky."

T: "okay, How's the moon and the sun on the sky right?"

On other occasion, pre-service teacher used explicit feedback as part of corrective feedback that tells students' incorrect utterance and gives the correct answer explicitly. For instance, one of groups answers the correct title of text but they pronounce it wrongly like in the following utterance.

\section{(2) S: "the grasshopper and the toad /tud"}

\section{T: "toad/tod not tud"}

\section{b. Evaluative Feedback}

Askew (2000) explained that evaluative feedback consist of approval (raise) and disapproval, confirmation, and encouragement. From the observation data, there were found many approval executed by pre-service teachers. Approval is a feedback that contains teacher's positive expression toward students' work. Like "good job", "good", "give applause", "you have done well", etc after the students' performance. Encouragement also given to the students who didnot want to perform like "it's okay", "just try it", "come on try it" etc. it is a moral support for students that pre service believe about the students' ability. Somehow, no confirmation found in pre-service teachers teaching and learning process. 


\section{c. Descriptive feedback}

Askew (2000) stated that descriptive feedback is specific information about what students do well, what they need to improve, and how they can improve. The following utterance was found in pre-service teachers' oral feedback during apprenticeship program.

(3)T: the third group, you have done well. Only the voiceis not really loud. I heard one of you said 'I was studied'

From the above utterance, pre-service teachergave oral feedback by described the information about theweakness of the students by saying that the students' voice is not loud enough that it may cause the other students could not hear what she/he said. This kind of information told the other weakness on the students' performance.

Data from observation and questionnaire indicated that pre-service teachers concern to the mistakes in grammar, pronunciation and vocabulary rather than to the content or the whole utterances of the students. Table 3 presents the types of feedback that used by pre-service teachers when they have to deal with grammar, pronunciation and vocabulary from the questionnaire answer.

Table 3 types of oral feedback

\begin{tabular}{|c|c|c|c|}
\hline Type of feedback & Concern & Number & Percentage \\
\hline Descriptive & \multirow{3}{*}{$\begin{array}{c}\text { Grammatical } \\
\text { Mistakes }\end{array}$} & 2 & 10 \\
\hline Evaluative & & 5 & 25 \\
\hline Corrective & & 13 & 65 \\
\hline Corrective & \multirow[t]{3}{*}{ Mispronunciation } & 18 & 90 \\
\hline Evaluative & & 1 & 5 \\
\hline Descriptive & & 1 & 5 \\
\hline Descriptive & \multirow{3}{*}{$\begin{array}{l}\text { Inappropriate } \\
\text { Vocabularies }\end{array}$} & 6 & 30 \\
\hline Evaluative & & 5 & 35 \\
\hline Corrective & & 9 & 45 \\
\hline
\end{tabular}

As it is displayed in table 3,65\% pre-service teachers used corrective feedback to deal with grammatical mistakes, $25 \%$ used evaluative and $10 \%$ used descriptive feedback. In respond to students' mispronunciations, 90\% pre-service teachers used corrective feedback, and 5\% each for evaluative and descriptive feedback. Moreover, pre-service respond to inappropriate vocabularies are $45 \%$ used corrective feedback, $35 \%$ evaluative feedback and $30 \%$ descriptive feedback 


\section{CONCLUSION}

From the discussion and finding, it can be concluded that pre-service teachers' were aware by the important of oral feedback to correct students' mistakes, clarify the incorrect information, correct the students' pronunciation, and restate the correct form of students' utterances. Unfortunately in the teaching and learning process many of pre-service teachers did not execute oral feedback when they have to. Most of the oral feedback given to the students were focused on mispronunciation, grammar and vocabulary. Pre-service teachers seems did not notice misinformation mistakes and did not really aware of giving advice on students' performance as the improvement strategy.

\section{ACKNOWLEDGEMENT}

This research was supported by the research fund provided by Directorate of Research and Community Service, Directorate General for Research and Development, Ministry of Research, Technology and Higher Education. In accordance with the Research Contract for Fiscal Year 2019. The research scheme was "Penelitian Dosen Pemula".

\section{REFERENCES}

Alagozlu, N. (2016). Pre-Service EFL Teachers' Professional Self-Concept: English Teaching Efficacy, Self Reported English Proficiency and Pedagogical Strategies: A Case in Turkish Context. International Conference on Teaching and Learning English as an Additional Language, GlobELT 2016, 14-17 April 2016, Antalya, Turkey.

Asik, A. \& Gonen, S. I. K. (2016). Pre-service EFL Teachers' reported perceptions of their development through SETT experience. ISSN: 19463014. Jounal Homepage: http//www.landfonline.com/Loi/rcdi20. Routledge.

Askew, S. (2000). Feedback for Learning. London: Routledge Falmer.

Bailey, K. D. (1994). Method of Social Research. Basingstoke: Macmillan.

Brown, Doughlas. 2003. Language Assessment Principles and Classroom Practices. California : San Fransisco State University.

Carlin, R. E.T. (2013). Pre-Service Teachers' Beliefs about the role of Thesis Supervisors: A case study. Gist education and leraning research journal. ISSN 1692-5777. No. 7, November 2013- pp.74-92.

Cohen, L., Manion, L. and Morrison, K. (2007). Research Method in Education sixth edition. London and New York: Routledge. 
Dornyei, Z. (2007). Research Methods in Applied Linguistics; Quantitative, Qualitative, and Mixed Methodologies. New York: Oxford University Press.

Dwiniasih. (2007). Pre-service teacher's problem during teaching practice. The first International conference on linguistics and english teaching ( $1^{\text {st }}$ ICLET) 2017 proceedings. ISBN: 978-602-71252-4-7. Pp. 134-143.

Ellis, R., Loewen, S., \& Erlan, R. (2006). Implicit and Corrective Feedback and the Acquisition of L2 Grammar. Studies in Second Language Acquisition, 28 (2), 339-368.

Hattie, J., Timperly, H. (2007). The power of feedback. Review of Educational Research, 77(1), 81-112.

Hyland, K. \& Hyland, F. (2006). Feedback on second language Students' writing language teaching, 39 (2), 83-101.

Kluger, A. N. \& Denisi, A. (2017). The Effects of Feedback Interventions on Performance: A Historical review, a meta Analysis and a preliminary feedback intervention theory. Psychological Bulleting, 119 (2), 254-284.

KOc, B. and Ilya, A. (2016). Exploring Pre-Service Language Teacher's Perceptions and Actual Practices of Giving Feedback in Micro Teaching. International Conference on Teaching and Learning English as an Additional Language, GlobELT 2016, 14-17 April 2016, Antalya, Turkey.

Mahdi, D and Saadany, N.E. (2013). Oral Feedback in the EFL Classroom. Malmo Hogskola.

McDonald, L. (2009). Responsive of Student Teacher to the Supervision of associate Teachers. Presented at the British Educational Research Associate Annual Conference, University of Manchester, 2-5 September 2009.

Melati, Y. D. A. (2014). Kinds of Teacher's Oral Feedback in Public Speaking Class. Satya Wacana Christian University.

Richards, J. S. and Schmidt, R. (2010). Longman Dictionary of Language and Teaching Applied Linguistics (4th ed.). Great Britain: Pearson Education Limited.

Sadler, R. (1989). Formative Assessment and Design of Instructional Science. 18.119-144.

Schon, D. (1983). The Reflective Practitioner - How Professionals think in action. New York: Basic Books. Inc.

Sultana, R. (2015). The Survey on Using Oral Corrective Feedback in ESL Classroom in Bangladesh Context. BRAC University Dhaka Bangladesh. 
${\text { Atikah } \text { Wati }^{* 1} \text {, Indra Yoga Prawiro }}^{* 2}$

PRE-SERVICE EFL TEACHERS' PERCEPTIONS AND ACTUAL PRACTICES OF GIVING ORAL FEEDBACK IN APPRENTICESHIP PROGRAM: EXPLORATORY STUDY

Yin, R. K. (2008). Case study research: Design and methods (4th ed.). Thousand Oaks, CA:SAGE Publications.

Yuksel, G.H. and Kavanoz, S. (2015). Influence of Prior Experiences On Preservice Language Teachers' Perception on Teaching. International Conference on Teaching and Learning English as an Additional Language, GlobELT Antalya, Turkey. 